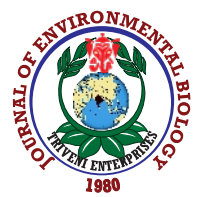

\title{
Evaluation of biomass and certain biochemical parameters of earthworm Drawida willsi in response to organic amendments of iron mine spoil
}

\author{
S. Nayak ${ }^{1}$ and C.S.K Mishra* \\ 'School of Life Sciences, Sambalpur University, Burla-768 019, India \\ ${ }^{2}$ Department of Zoology, Odisha University of Agriculture and Technology, College of Basic Science and Humanities, Bhubaneswar-751 003, India \\ *Corresponding Author Email : cskmishra@yahoo.com
}

\section{Abstract}

Aim: To evaluate the changes in the tissue protein, lipid peroxidation (LPX) levels, catalase (CAT) activity and biomass of earthworm, Drawida willsi in response to different organic amendments of iron mine spoil.

\begin{abstract}
Methodology: Farmyard manure, poultry manure, vermimanure and bio-fertilizer in various combinations were amended with the mine spoil prior to inoculation of the earthworm. Tissue protein, lipid peroxidation levels and catalase activity of the earthworm were measured over an incubation period of 42 days at an interval of 7 days. The percent change in biomass of the earthworm over the experimental period was assessed.
\end{abstract}

Results: Significant variation in the biochemical parameters and biomass of the earthworm were observed in response to amendments. The highest tissue protein (151.6 $\mathrm{mg} \mathrm{g}^{-1}$ tissue) was observed in spoil amended with VM and BF. The maximum lipid peroxidation level $\left(0.11 \mathrm{nmol} \mathrm{mg}^{-1}\right.$ protein) and catalase activity (0.59 nkat $\mathrm{mol}^{-1}$ protein) were recorded in control. The highest $(0.476 \mathrm{~g})$ biomass was observed in spoil with vermimanure and biofertilizer.

Interpretation: The results of this study proved that vermimanure with biofertilizer is the most suitable combination for amendment of iron mine spoil with least physiological stress on the earthworms.

Key words: Biomass, Drawida willsi, Iron mine spoil, Organic amendments

How to cite : Nayak, S. and C.S.K Mishra: Evaluation of biomass and certain biochemical parameters of earthworm Drawida willsi in response to organic amendments of iron mine spoil. J. Environ. Biol., 42, 169-175 (2021).
Spoil + Organic amendments + Bio-fertilizer+ Earthworms

T1: Spoil + FYM + Bio-fertilizer+ Earthworms

T2: Spoil + PM + Bio-fertilizer+ Earthworms

T3: Spoil + VC+ Bio-fertilizer+ Earthworms

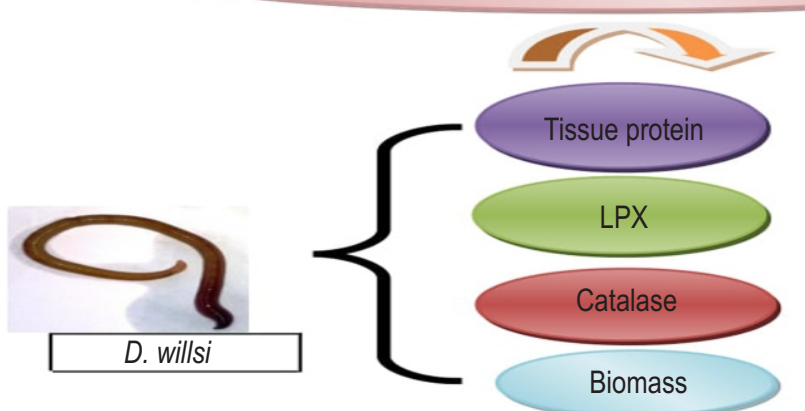




\section{Introduction}

Mining of metal ores have detrimental impact on the terrestrial and aquatic environment on a local and regional scale. Considerable quantity of solid wastes or spoil is generated during mining which is conventionally dumped on land or in aquatic systems causing serious ecological problems (Michelutti and Wiseman, 1995; Vega et al., 2004; Liu et al., 2005, Nayak et al., 2015). Remediation of contaminated mine spoils might include environment friendly options such as phyto-remediation (Vangronsveld and Cunningham, 1998; Lasat, 2000; Wong, 2003). A new generation of techniques proposes the use of organic matter and earthworm additions for the reclamation of spoils. Organic residues are widely used as soil amendments (Rees et al., 2001), and earthworms are expected to enhance microbial proliferation, ability of plants to tolerate contaminants and possibly accelerate soil detoxification by chelation (Sizmur et al., 2011a, b; Jusselme et al., 2013). Organic matter added to mine spoil undergoes a process of decomposition that proceeds at variable rates according to climate and soil conditions, the quality of organic inputs and soil biological activity (Lavelle et al., 1993; Srivastava et al., 2007). Animal dung composts obtained from cattle, hog and chicken dung are the principal organic sources applied to increase the fertility of degraded soils. However, vermimanure and biofertilizer have seldom been tried as suitable amendments for nutrient enrichment of mine spoils

Earthworms designated as soil ecosystem engineers are known to stimulate soil physical and microbiological processes with implications for organic matter turnover and nutrient release (Lavelle and Spain, 2001). These animals have been proposed as suitable candidates to accelerate soil restoration in mining areas (Boyer and Ratten, 2010). Earthworms in general are highly sensitive to the physical and chemical quality of soil and tend to perform their ecological functions most efficiently in a congenial habitat. Since earthworms feed on organic matter, the quality of organics in soil can influence their growth and physiology.

The most suitable food is expected to exert the least physiological stress on the animals. An alteration in the feeding environment can affect their activities and enhance physiological stress, which can be evaluated by selecting suitable biomarkers in these animals. Biomass, lipid peroxidation level and catalase activity in earthworms have earlier been evaluated by various workers as markers to indicate physiological stress due to alterations in physico-chemical quality of soil (Sumathi and Thaddeus, 2013; Biradar and Biradar,2015; Samal et al., 2017; Nayak et al., 2018; Samal et al., 2019 a,b; Mishra et al., 2020). The tropical epigeic earthworm, Drawida willsi is abundantly found in the surface soil of iron ore mining area of Odisha with potential to facilitate reclamation of mine spoil through suitable nutrient fortification. To determine the most suitable organic amendment with minimal physiological stress on the earthworm, this study was conducted to evaluate the effects of various organic and biofertilizer combinations in mine spoil on its biomass, tissue protein, lipid peroxidation levels and catalase activity.

\section{Materials and Methods}

Collection of mine spoil: The mine spoil was collected at random from 5-year-old dumps located in the iron ore mining area of Badbil in Keonjhar district of Odisha, India. The samples were packed in gunny bags and transported to the campus of Odisha University of Agriculture and Technology, Bhubaneswar, India for the experiment. The spoil samples were mechanically ground and mixed properly before transferring into the experimental pots.

Earthworm sampling: The earthworm D. willsi was sampled from the organically managed agricultural fields of the University. The farm yard manure (FYM), poultry manure (PM), vermimanure (VM) and biofertilizer (BF) were procured from the local farms.

Experimental set up: Four sets of pots:C- Control (Spoil $+E), T_{1}$ $($ Spoil $+F Y M+B F+E), T_{2}($ Spoil $+P M+B F+E)$ and $T_{3}($ Spoil + VM $+B F+E)$ were used for pot experiment. $A 500 \mathrm{~g}$ of finely sieved spoil was transferred into each experimental pot. As per the recommended dose of manure application (Agronika, 2005), $166.6 \mathrm{gm}$ of farm yard manure and poultry manure were added to $\mathrm{T}_{1}$ and $\mathrm{T}_{2}$ pots and $17 \mathrm{~g}$ of vermimanure to $\mathrm{T}_{3}$ pot respectively. To each experimental pot, except control, $20 \mathrm{~g}$ of biofertilizer was added. The spoil was thoroughly mixed with the treatment materials. As per predetermined water holding capacity of spoil, $30 \%$ moisture level was maintained in all the treatments. Twenty clitellated earthworms of approximately equal weight were inoculated into each pot after keeping them in $100 \mathrm{ml}$ beakers with distilled water for $15 \mathrm{~min}$ to clear their gut content. The pots were covered with wet gunny bags and kept in the laboratory. Sampling of earthworms was made from each treatment pot at an interval of 7 days up to 42 days for biochemical analysis.

Biochemical assay: The sampled earthworms (2 from each pot) were thoroughly washed with distilled water and transferred to wet blotting paper to clear their gut content. The animals were then sacrificed and cut into pieces in petridishes with the help of a sharp edged razor. The tissue samples were cleaned and weighed quickly on a top pan balance to avoid post mortal tissue degradation. The samples were then homogenized with potassium phosphate buffer $(0.05 \mathrm{M}, \mathrm{pH}$ 7.4) using a homogenizer (REMI) in chilled condition.

The homogenates were centrifuged for $15 \mathrm{~min}$ at 10,000 rpm in a refrigerated centrifuge (REMI C-24BL). Aliquots of supernatant were collected in eppendorf tubes and stored at$20^{\circ} \mathrm{C}$ in a deep freezer (Cellfrost) until further use. The total tissue protein of earthworms was estimated by Folin-Ciocalteau method (Lowry et al., 1951). The reaction mixture of solution $\mathrm{A}$ $\left(0.1 \mathrm{M} \mathrm{NaOH}\right.$ and $\left.2 \% \mathrm{Na}_{2} \mathrm{Co}_{3}\right)$, solution $\mathrm{B}\left(0.5 \% \mathrm{CuSo}_{4}\right)$, solution $\mathrm{C}$ $\left(1 \% \mathrm{KNaC}_{4} \mathrm{H}_{4} \mathrm{O}_{6} \cdot 4 \mathrm{H}_{2} \mathrm{O}\right)$ were mixed in sample in $100 \mathrm{~A}: 2 \mathrm{~B}: 2 \mathrm{C}$ ratio followed by addition of Folin-Ciocalteau phenol. The samples were read at $700 \mathrm{~nm}$ on a UV-VIS spectrophotometer taking bovine serum albumin as standard. The amount of protein was expressed in $\mathrm{mg} \mathrm{g}^{-1}$ tissue. Lipid peroxidation level was 
measured by monitoring the formation of thiobarbituric acid reactive substances (TBARS) and its secondary product, malondialdehyde (MDA) following the method of Ohkawa et al. (1979). The samples were treated with Thiobarbituric acid (TBA) in an acidic medium of $20 \%$ trichloroacetic acid ( $\mathrm{pH} 3.5$ ) and $8.1 \%$ sodium dodecyl sulphate (SDS). The volume of the mixture was made upto $1 \mathrm{ml}$ by adding distilled water and heated for $60 \mathrm{~min}$ in boiling water in the presence of butylate dihydroxytoluene (BHT). After cooling, the mixture was centrifuged for $15 \mathrm{~min}$ at 10,000 $\mathrm{rpm}$ and the samples were read at $532 \mathrm{~nm}$. Lipid peroxidation level was expressed as nmol $\mathrm{mg}^{-1}$ protein. Catalase activity was estimated following the method of Cohen et al. (1970). Reading was taken every $30 \mathrm{sec}$ at $340 \mathrm{~nm}$ wavelength on a UV-Vis Spectrophotometer (Systronics) taking sample along with phosphate buffer ( $\mathrm{pH} 7.4,0.05 \mathrm{M})$ and hydrogen peroxide. Catalase activity was expressed in $\mathrm{U} \mathrm{mg}^{-1}$ protein.

Estimation of biomass: Each earthworm was weighed on a digital top pan balance (Isuzu) before inoculation and after incubation period for each treatment pot and the mean weight was computed in milligram (mg).

Statistical analysis: All the experiments were conducted in triplicate. The data were analyzed by One-way analysis of variance (ANOVA) at $P<0.05$ using SPSS 20 software.

\section{Results and Discussion}

The changes in various biochemical parameters of the earthworm in response to different organic amendments in iron mine spoil over the incubation period has been depicted in (Fig. 13). The percent change in the biomass of earthworm has been presented in (Fig. 4). On the $7^{\text {th }}$ day, the tissue protein content increased by $162 \%, 198.9 \%$ and $204.0 \%$ in T1, T2 and T3 respectively with respect to the control, while on 14th day the changes were $168.2 \%, 201.8 \%$ and $212.1 \%$. An identical trend was observed on the $21^{\text {st }}$ day with $166.5 \%, 193.4 \%$ and $202.7 \%$ increase in protein in T1, T2 and T3 respectively relative to control. On the $28^{\text {th }}$ and $35^{\text {th }}$ days, the changes were $174.5 \%$, $194.4 \%, 196.2 \%, 174.2 \%, 207.8 \%$ and $260.1 \%$. Protein content further increased by $179.8 \%, 246.3 \%$ and $268.3 \%$ on the $42^{\text {nd }}$ day. Although, the earthworms in all the organically amended spoils indicated relatively higher protein level with respect to control, the highest value was obtained from the animals inoculated in $\mathrm{T}_{3}$. ANOVA indicated a significant variation $(P<0.05)$ in the protein content between treatments.

Protein is one of the major building blocks and an important source of energy for animal tissue. Reports on the effects of organic matter in soil on earthworm tissue protein are rare. However, it is well known that protein contributes significantly to the total biomass in animals. Fonte et al. (2009) reported that earthworm population and average biomass were significantly higher in soil rich in organic matter. They also proposed that the quality of organics too influence the feeding and growth of the worms. Several authors have shown that reduction in worm protein content was one of the primary effects of an adverse environment. Ismail et al. (1997) reported that reduction in the total protein content of earthworm (A. caliginosa) was due to the toxic effects of the pesticide chlorfluazuron in soil. Mosleh et al. (2003) too reported reduction in tissue protein in E. fetida in response to pesticide isoproturon. Recently, Nayak et al. (2018) and Samal et al. (2019) reported that hyper toxicity in soil due to phosphogypsum, paper mill sludge and pesticides could reduce tissue protein levels in Glyphidrillus tuberosus, Lampito mauritii, Drawida willsiand Eudrillus eugeniae.

The reduction in protein content may also be ascribed to the enhanced level of catabolism of proteins in response to worm energy demand as suggested for an isopod in response to parathion (Ribeiro et al., 2001). In the present study, lower protein content in $C, T_{1}$ and $T_{2}$ is likely due to reduced food intake and assimilation by $D$. willsi. The mean LPX levels in the earthworm recorded on the day 1 were found to be $0.12 \pm 0.01,0.15 \pm 0.01$, $0.07 \pm 0.005,0.08 \pm 0.01 \mathrm{nmol} / \mathrm{mg}$ protein in C, T1, T2, T3 respectively (Fig. 2). There was an increase in the LPX levels till day 14 after which it declined up to day 42 . The LPX levels on the last day of incubation were $0.11 \pm 0.01,0.09 \pm 0.005,0.01 \pm 0$, $0.01 \pm 0.005 \mathrm{nmol} / \mathrm{mg}$ protein in C, T1, T2, T3 respectively.

On the $7^{\text {th }}$ day, the LPX levels increased by $90 \%, 45 \%$ and $35 \%$ in T1, T2 and T3 respectively with respect to control, while on the $14^{\text {th }}$ day the increases were $88.8 \%, 49.4 \%$ and 38.8 $\%$. On the $21^{\text {st }}$ day, the LPX levels decreased by $93.75 \%, 43.75 \%$ and $37.5 \%$ in T1, T2 and T3 respectively. On $28^{\text {th }}$ and $35^{\text {th }}$ days there was further decrease in LPX levels by $100,50 \%, 41.6 \%$ and $83.3 \%, 75 \%, 33.3 \%$ in T1, T2, T3 respectively. On the $42^{\text {nd }}$ day the LPX reduction with respect to control were found to be $90.9 \%, 9.09 \%$ and $9.09 \%$ in T1, T2 and T3 respectively. ANOVA indicated that variations in the LPX levels between treatments were significant $(P<0.05)$. In the present study, as compared to control, the maximum decrease in lipid peroxidaton was found in $T_{3}$, followed by $T_{2}$ and $T_{1}$, indicating that $T_{3}$ caused minimal oxidative stress on the animals and, therefore, can be considered as the best amendment option for reclamation of iron mine spoil facilitated by earthworms.

Lipid peroxidation is a chain reaction initiated by hydrogen abstraction or addition of oxygen radical, resulting in oxidative damage of polyunsaturated fatty acids (Halliwell and Gutteridge, 1984). Numerous studies have shown that unfavorable environmental conditions and exposure to xenobiotics lead to the generation of reactive oxygen species (ROS) followed by increase in lipid peroxidation level. Labrot et al. (1996) elucidated that lead and uranium can induce lipid peroxidation in earthworms. Earlier research findings (Rimmer and Smith, 2009; Bednarz, 2019; Bednarz et al., 2019) have indicated that the total antioxidant capacity values were higher for soils rich in organic matter and were positively correlated with percent organic carbon content. They also reported that the level 


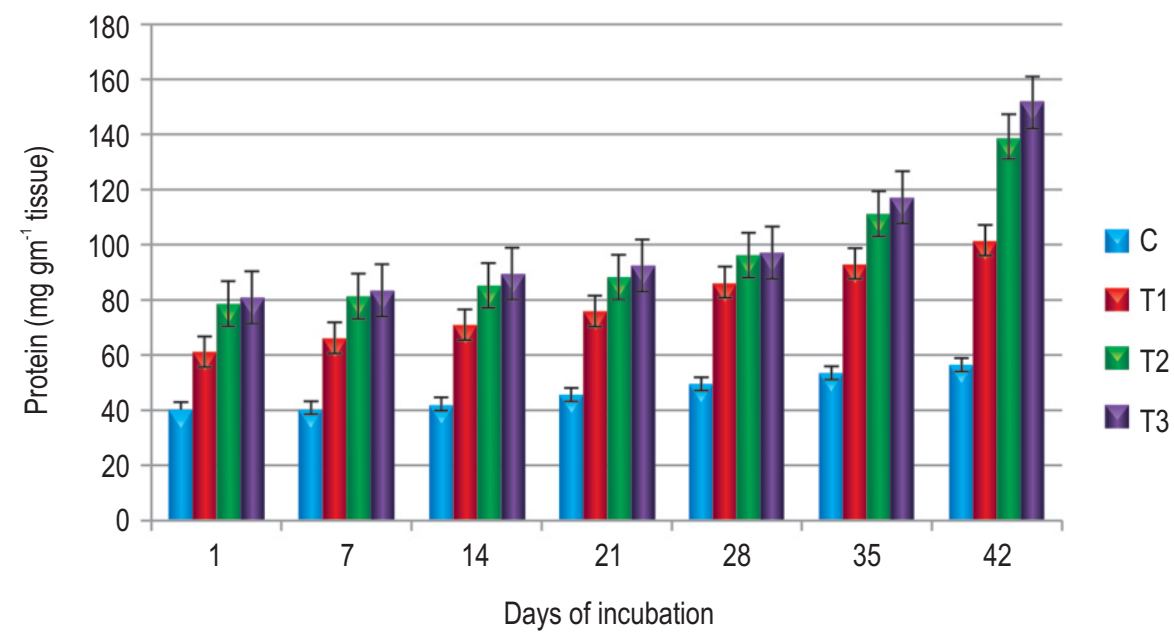

Fig.1: Protein content in D. willsi in organically amended mine spoil. C: Control (Spoil +E); $T_{1}(S p o i l+F Y M+B F+E) ; T_{2}(S p o i l+P M+B F+E)$ and $T_{3}(S p o i l$ $+\mathrm{VM}+\mathrm{BF}+\mathrm{E})$. Values are mean \pm S.D.

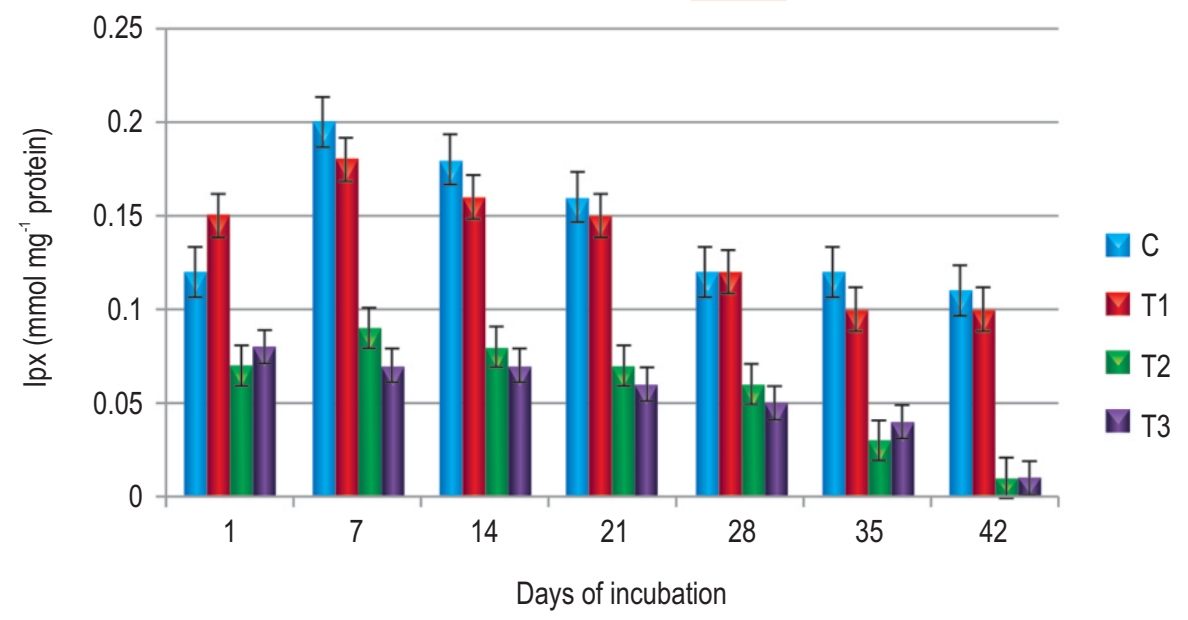

Fig. 2: Lipid peroxidation level in D. willsi in the organically amended mine spoil. C: Control (Spoil $+E), T_{1}(S p o i l+F Y M+B F+E), T_{2}(S p o i l+P M+B F+E)$ and $\mathrm{T}_{3}(\mathrm{Spoil}+\mathrm{VM}+\mathrm{BF}+\mathrm{E})$. Values are mean $\pm \mathrm{S} . \mathrm{D}$.

of antioxidants is dependent on the quality of organic present in soil. Since antioxidants minimize oxidative damage due to free radicals generated during lipid peroxidation, it is likely that the quantity and quality of organic matter modulate the damages caused due to physiological stress in soil fauna, including earthworms. CAT activities in the earthworm on day 1 were recorded as $0.66 \pm 0.015,0.41 \pm 0.01,0.42 \pm 0.015,0.3 \pm 0 \mathrm{nkat} / \mathrm{mol}$ protein in $\mathrm{C}, \mathrm{T} 1, \mathrm{~T} 2, \mathrm{~T} 3$ respectively (Fig. 3).

The enzyme activity was invariably higher in earthworms from control in comparison to those from organically amended spoils. CAT activity initially increased and then got stabilized towards the end of the incubation period irrespective of treatments. The activity of this enzyme on the day 42 were recorded as $0.59 \pm 0.005,0.39 \pm 0,0.36 \pm 0,0.2 \pm 0.005 \mathrm{nkat} / \mathrm{mol}$ protein in C, T1, T2, T3 respectively. On the $7^{\text {th }}$ day, CAT activity decreased by $60.56 \%, 63.3 \%$ and $42.2 \%$ in T1, T2 and T3 respectively with respect to control, while on $14^{\text {th }}$ day the reductions were $69.5 \%, 62.3 \%$ and $39 \%$. On the $21^{\text {st }}$ day the enzyme activity decreased by $69.2 \%, 61.5 \%$ and $38.4 \%$. On the $28^{\text {th }}$ and $35^{\text {th }}$ days, the enzyme activities further decreased by 66.1 $\%, 56.45 \%, 38.7 \%$ and $63.3 \%, 55 \%, 35 \%$ in T1, T2, T3 respectively with respect to control. On the $42^{\text {nd }}$ day, CAT activity decreased by $59.3 \%, 52.5 \%$ and $30.5 \%$. ANOVA indicated that 


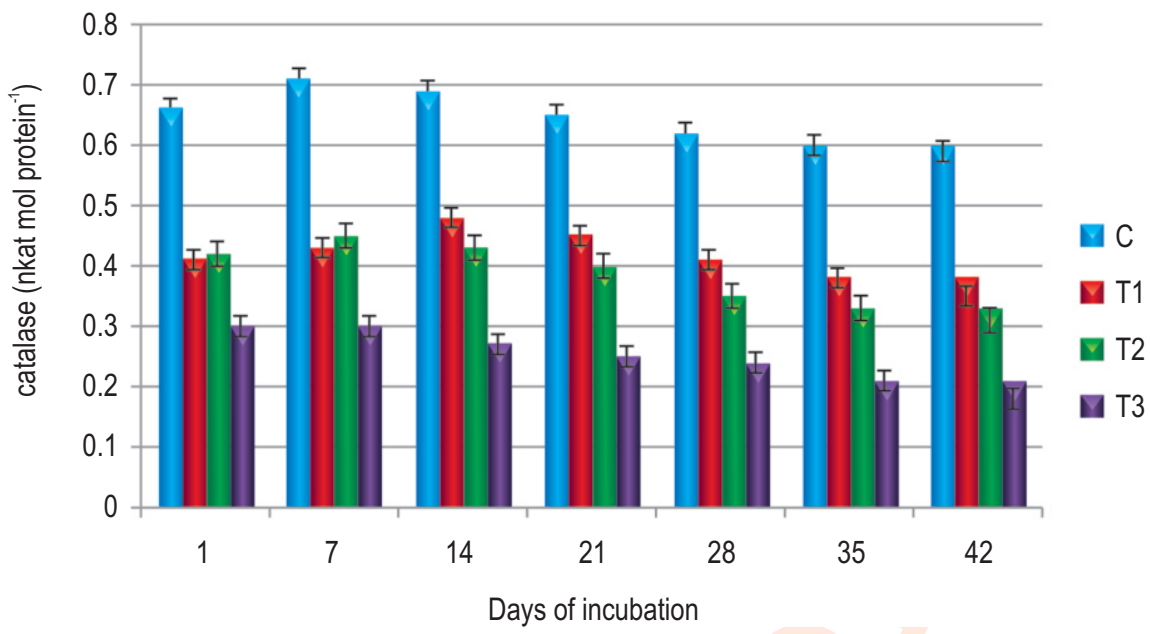

Fig. 3: Catalase activity in $D$. willsi in organically amended mine spoil. C: Control (Spoil $+E), T_{1}($ Spoil $+F Y M+B F+E), T_{2}(S p o i l+P M+B F+E)$ and $T_{3}$ $($ Spoil $+\mathrm{VM}+\mathrm{BF}+\mathrm{E})$. Values are mean \pm S.D.

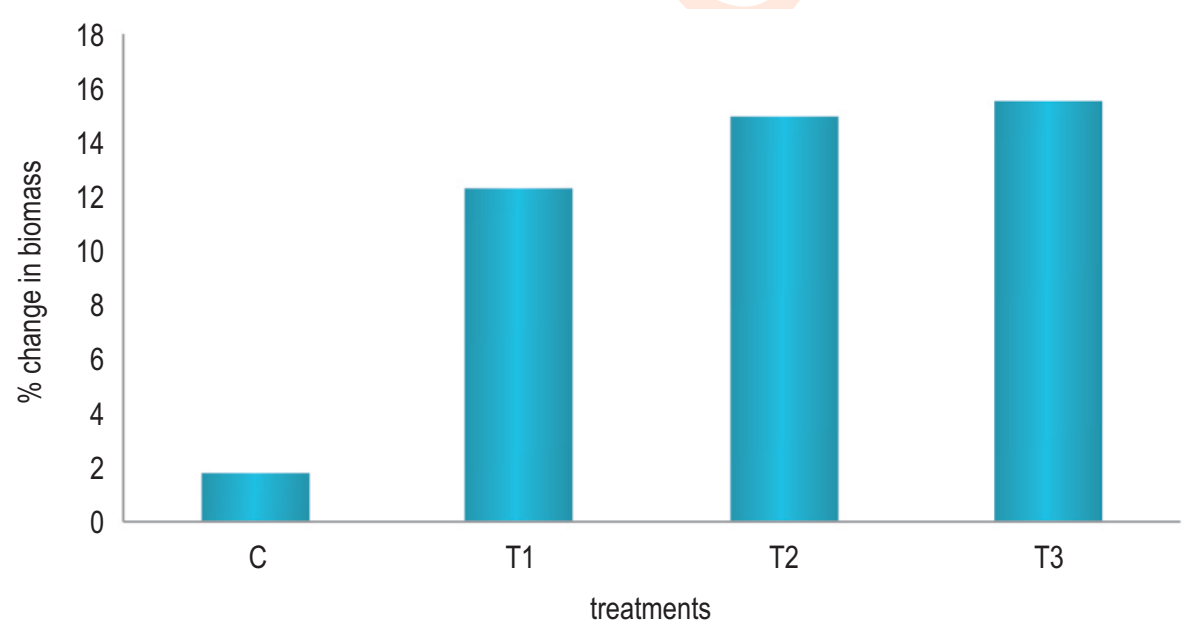

Fig. 4: Percent change in biomass of $D$. willsi in organically amended mine spoil. C: Control (Spoil $+E), T_{1}(S p o i l+F Y M+B F+E), T_{2}(S p o i l+P M+B F+E)$ and $T_{3}($ Spoil $+V M+B F+E)$. Values are mean \pm S.D.

the activity of CAT in the earthworm between treatments was statistically significant $(P<0.05)$. CAT is a useful enzyme released in animals under physiological stress to scavenge reactive oxygen species (Roubalová et al., 2015). This enzyme protect the cells against oxidative stress (Abott et al., 2009). The prevention of oxidation is an essential process in all aerobic organisms as decreased antioxidant protection might lead to cytotoxicity, mutagenesity or carcinogenicity (Mates, 2000). Ravikiran and Aruna (2010) have proposed that catalase is a sensitive enzyme marker to indicate physiological stress on $E$ eugeniae. Cao et al. (2017) reported an increase in CAT activity in E. fetida in response to bacterial toxins in soil. The maximum catalase activity in $D$. willsii in
C relative to $\mathrm{T} 1, \mathrm{~T} 2$ and $\mathrm{T} 3$ could be linked to highest lipid peroxidation level indicating that earthworms experienced maximum oxidative stress in control while reduced activities in other treatments indicates the ambient environment for better survival of earthworms by protecting the cells against oxidative stress. The biomass in earthworms was found to increase over the incubation period. The percent change of biomass of earthworms on day 42 with respect to day 1 were found to be $1.69 \%, 12.2 \%, 14.84 \%$, $15.42 \%$ in control, $\mathrm{T}_{1}, \mathrm{~T}_{2}$ and $\mathrm{T}_{3}$ treatments, respectively (Fig. 4).

The maximum percent increase in the biomass was recorded in $T_{3}$ followed by $T_{2}, T_{1}$ and control treatments. Variation 
in the biomass of earthworms in different amendments was statistically significant $(p<0.05)$. Rathinamala et al. (2008) reported variation in the body weight of $E$. fetida and $E$. eugeniae feeding on different types of organic wastes. Buchnan et al. (1988) had proposed that vermicompost has more available nutrients than organic wastes from which they are produced. In the present study, the increased biomass of earthworms in organically amended spoils were noticeably higher relative to control. Sumathi and Thaddeus (2013) had noticed significant increase in the biomass of $E$. eugeniae cultured in organic rich diet. Biradar and Biradar (2015) observed significant variation in biomass gain of Perionyx excavatus fed with different combination of organic wastes. Since earthworms in general feed on soil organic matter for their growth and reproduction, availability of organics in $T_{1}, T_{2}$ and $T_{3}$ treatments enhanced the earthworm biomass better than unamended control mine spoil, which was found deficient in organic matter.

Consistent increase in biomass, tissue protein along with lower lipid peroxidation level and catalase activity in organically amended iron mine spoils indicates that $D$. wilsi had experienced less physiological stress in these treatments relative to unamended spoil. Non availability of adequate organics in the control spoil possibly enhanced the stress on $D$. willsi with least increment in biomass, tissue protein, high lipid peroxidation level and catalase activity. The results of the study also suggest that vermimanure and biofertilizer appear to be the most suitable amendment combination to facilitate reclamation of iron mine spoil using $D$. willsi.

\section{Acknowledgment}

The authors sincerely acknowledge the financial support received from The University Grants Commission, New Delhi in form of a major research project to the corresponding author.

\section{Add-on Information}

Authors' contribution: S. Nayak: Conducted the experiment and did data analysis \& wrote the paper; C.S.K. Mishra: Designed the experiment and reviewed the paper

Research content: The research contents is original and has not been published elsewhere

Ethical approval: The experiment on the animal used in experiment of MRN/1308 has been approved by Ethics committee of the University.

Conflict of interest: The author declares that there is no conflict of interest.

\section{Data from other sources: NotApplicable}

Consent to publish: All authors agree to publish the paper in Journal of Environmental Biology.

\section{References}

Abbott, D.A., E. Suir, G.H. Duong, E.D. Hulster, J.T. Pronk and A.J. Maris: Catalase over expression reduces lactic acid induced oxidative stress in Saccharomyces cerevisiae. Appl. Environ. Microbiol., 75, 2320-2325 (2009).

Agronika: Official Publication of Government of Odisha, India for fertilizer doses. pp. 541-550 (2005).

Bednarz, B.S.: Total antioxidant capacity as an important element in the assessment of soil properties for the production of high quality agricultural and horticultural raw materials with health promoting properties. ActaAgroph., 26, 61-66 (2019).

Bednarz, B.S., A. Krzepilko, A. Jamoilkowska, M. Kopacki and E. Patkowska: Total antioxidant activity of varying quality soils. Fresenius Env. Bull., 28, 4523-4528 (2019).

Biradar, P.M. and V.A. Biradar: Influence of organic wastes on the biology of epigeic earthworm, Perionyx excavatus during different seasons. J. Enviro. Biol., 36,1095-1100 (2015).

Boyer, S. and S.D. Ratten: The potential of earthworms to restore ecosystem services after opencast mining-A review Basic. Appl. Ecol., 11,196-203 (2010).

Buchanan, M.A., C. Russel and S.D. Block: Chemical characterization and nitrogen mineralization potentials of vermicompost derived from differing organic wastes. In: Earthworms in Waste and Environmental Management. (Eds.: C.A. Edwards and E.F. Neuhauser). SPBAcademic Press, The Hague, pp. 231-239 (1988).

Cao, Q., A.D. Steinman, L. Yao and L. Xie: Toxicological and biochemical responses of the earthworm Eisenia fetida to cyanobacteria toxins. Scientific Report, 7, 15954 (2017).

Cohen, G., D. Dembiec and J. Marcus: Measurement of catalase activity in tissue extracts. Anal. Biochem., 34, 30-38 (1970).

Fonte, J.S., T. Winsome and J. Six: Earthworm population in relation to soil organic matter dynamics and management of California tomato cropping systems Appl. Soil Ecol., 41, 206-214 (2009).

Halliwell, B. and M. Gutteridge: Oxygen toxicity, oxygen radicals, transition metals and disease. Bioch. J., 219, 1-14 (1984).

Ismail, S.S., Y.M. Mosleh, Y.Y. and T.M . Ahmed: The activities of some proteins and protein related enzymes of earthworms as biomarker for atrazine exposure. Toxicol. Environ. Chem., 63, 141-148 (1997).

Jusselme, M.D., E. Miambi, P. Mora, M. Diouf and C. Rouland-Lefevre: Increased lead availability and enzyme activities in root-adhering soil of Lantana camara during phytoextraction in the presence of earthworms. Sci. Total Environ., 445-446, 101-109 (2013).

Lasat, M.M.: Photoextraction of metals from contaminated soil: A review of plant/soil/metal interaction and assessment of pertinent agronomic issues. J. Hazard. Subst. Res., 2, 1-25 (2000).

Lavelle, P., E. Blanchart, A. Martin, S. Martin, I. Barois, F. Toutain, A. Spain, and R. Schaefer: A hierarchical model for decomposition in terrestrial ecosystems. Application to soils in the humid tropics, Biotropica, 25, 130-150 (1993).

Lavelle, P. and A.V. Spain: Soil Ecology. Kluwer Academic Publishers, Dordrecht/Boston/London (2001). doi: 10.1007/0-306-48162-6

Liu, Y.S., Y. Gao, K.W. Wang, X.H. Mai, G.D. Chen and T.W. Xu: Etiologic study on alimentary tract malignant tumor in villages of high occurrence. China Trop. Med., I15, 1139-1141 (in Chinese, with English abstract) (2005).

Labrot, F., D. Ribera, M.S. Denis and J.F. Narbonne: In-vitro and in-vivo studies of potential biomarkers of lead and uranium contamination: lipid peroxidation, acetylcholinesterase, catalase and glutathione peroxidase activities in three non-mammalian species. 
Biomarkers, 1, 1-14 (1996).

Lowry, O.H., N.J. Rosebrough and A.L. Farr: Protein measurement with the Folin phenol reagent. J. Biol. Chem., 193, 265-275 (1951).

Mates, M.: Effects of antioxidant enzymes in the molecular control of reactive oxygen species toxicology. Toxicology, 153, 83-104 (2000).

Michelutti, B. and M. Wiseman: Environmental Restoration of the Industrial City. (Eds.: R. Lal and B.A. Stewart). Springer-Verlag, Berlin, pp. 135-141(1995).

Mishra, C.S.K., S Samal., A Rout., A. Pattanayak and P. Acharya Evaluating the implications of moisture deprivation on bacterialfungal population, exoenzyme activities of the organic substrate and certain biochemical parameters in the earthworm Eudrilus eugeniae (Kinberg). Inverteb. Surviv. J., 17,1-8 (2020).

Mosleh, Y.M., S. Paris-Palacios, M. Couderchat and G .Vernet: Effects of the herbicide isoproturon on survival, growth rate and protein content of mature earthworms (Lumbricus terrestris L.) and its fate in the soil. Appl. Soil Ecol., 23, 69-77 (2003).

Nayak, S., C.S.K. Mishra and S. Mohanty: Remediation of iron mine spoil by organic amendments: Influence on chemical properties, bacterial-fungal population and growth of Acacia mangium. The Ecoscan, 9, 169-173 (2015).

Nayak, S., C.S.K. Mishra, B.C. Guru and S. Samal: Histological anomalies and alterations in enzyme activities of the earthworm Glyphidrillus tuberosus exposed to high concentrations of phosphogypsum. Environ. Monit. Assess., 190, 529 (2018).

Ohkawa, H., N. Ohishi and K. Yagi: Assay for lipid peroxides in animal tissues by thiobarbituric acid reaction. Anal. Biochem., 95, 351-358 (1979).

Rathinamala, J., S. Jayashree and P. Lakshmana Perumalsamy: Potential utilization of domestic wastes as a suitable experimental diet to enhance the biomass of Eudrilus eugeniae in various seasons. Ecol. Environ. Conserv., 14, 43-50 (2008).

Ravi Kiran,T. and H.K. Aruna: Antioxidant enzyme activities and markers of oxidative stress in the life cycle of earthworm, Eudrilus eugeniae Antioxidant defences in the life cycle of earthworm. Italian J. Zool., 77, 144-148 (2010).

Rees, R.M., B.C. Ball, C.D. Campbell and C.A. Waston: Sustainable Management of Soil Organic Matters. CABI Publishing, New York (2001)

Ribeiro, S., J.P. Souza, A.J.A. Nogueira and A.M.V.M. Soares: Effect of endosulfan and parathion on energy reserves and physiological parameters of the terrestrial isopod Porcellio dilatatus. Ecotoxicol. Environ. Saf., 49, 131-138 (2001).
Rimmer, D.L. and A.M. Smith: Antioxidants in soil organic matter and in associated plant materials. Euro. J. Soil Sci., 60,170-175 (2009).

Roubalová, R., P. Procházková, J. Dvořák, F. Škanta and M. Bilej: The role of earthworm defense mechanisms in ecotoxicity studies. Invert. Surv. J., 12, 203-213 (2015).

Samal, S., C. S. K. Mishra and S. Sahoo: Morphohistological and enzymatic alterations in earthworms Drawida willsi and Lampito mauritii exposed to urea, phosphogypsum and paper mill sludge. Chem. Ecol., 33, 762-766 (2017)

Samal, S., C.S.K. Mishra and S. Sahoo: Setal-epidermal, muscular and enzymatic anomalies induced by certain agrochemicals in the earthworm Eudrilus eugeniae (Kinberg). Enviro. Sci. Pollu. Res., 26, 8039-8049 (2019a).

Samal, S., C.S.K. Mishra and S Sahoo: Evaluating the effects of elevated concentrations of urea, phosphogypsum and paper mill sludge on soil chemical, microbial and exoenzyme dynamics. Int. J. Environ. Technol. Manag., 22, 207-219 (2019b)

Sizmur, T., B. Palumbo-Roe, M.J. Watts and M.E. Hodson: Impact of the earthworm Lumbricus terrestris (L.) on $\mathrm{As}, \mathrm{Cu}, \mathrm{Pb}$ and $\mathrm{Zn}$ mobility and speciation in contaminated soils. Environ. Pollut., 159, 742-748 (2011a).

Sizmur, T., E.L. Tilston, J. Charnock, B. Palumbo-Roe, M.J. Watts and M.E. Hodson: Impacts of epigeic: Anecic and endogeic earthworms on metal and metalloid mobility and availability. J. Environ. Monit., 13, 266-273 (2011b).

Srivastava, R., D. Roseti and A.K. Sharma: The evaluation of microbial diversity in a vegetable based cropping systam under organic farming practices. Appl. Soil Ecol., 36, 116-129 (2007).

Sumathi, G. and A. Thaddeus: Impact of organic rich diet on gut enzymes, microbes and biomass of earthworm, Eudrilus eugeniae. J. Enviro. Biol., 34, 515-520 (2013).

Saad, M.M.I., Y.M. Ahmed, Y.Y.I. Mosleh and M.T. Ahmed: The activities of some proteins and protein related enzymes of earthworms as biomarker for atrazine exposure. Toxicol. Environ. Chem., 63, 141-148(1997).

Vangronsveld, J. and S.D. Cunningham: Metal-Contaminated Soils: Insitu Inactivation and Phytorestoration. Springer, New York (1998).

Vega, F.A., E.F. Covelo, M.L. Andrade and P. Marcet: Relationships between heavy metals content and soil properties in mine soils. Anal. Chim. Acta., 524, 141-150 (2004).

Wong, M.H.: Ecological restoration of mine degraded soils, with emphasis on metal contaminated soils. Chemosphere, 50, 775-780 (2003). 